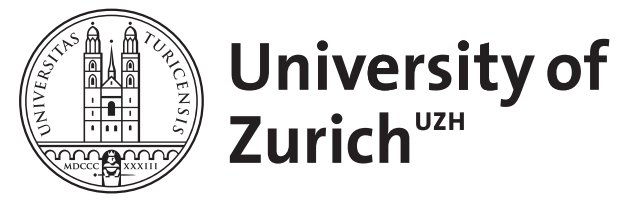

Zurich Open Repository and Archive

University of Zurich

University Library

Strickhofstrasse 39

CH-8057 Zurich

www.zora.uzh.ch

Year: 2017

Bibliographie raisonnée zur arabischen Papyrologie: Neuerscheinungen 2016 und Nachträge 2013-2015: Gruber, Christiane, „From Prayer to Protection: Amulets and Talismans in the Islamic World"

Thomann, Johannes

DOI: https://doi.org/10.1515/islam-2017-0030

Posted at the Zurich Open Repository and Archive, University of Zurich

ZORA URL: https://doi.org/10.5167/uzh-141229

Journal Article

Published Version

Originally published at:

Thomann, Johannes (2017). Bibliographie raisonnée zur arabischen Papyrologie: Neuerscheinungen 2016 und Nachträge 2013-2015: Gruber, Christiane, „From Prayer to Protection: Amulets and Talismans in the Islamic World“. Der Islam, 94(2):539-540.

DOI: https://doi.org/10.1515/islam-2017-0030 


\title{
Reviews
}

\section{Bibliographie raisonnée zur arabischen Papyrologie: Neuerscheinungen 2016 und Nachträge 2013-2015}

\author{
https://doi.org/10.1515/islam-2017-0030
}

Besprochen von Berkes, Lajos (Berlin) / Bsees, Ursula (Tübingen) / Daga Portillo, Rocio (München) / Garosi, Eugenio (Basel/München) / Kaplony, Andreas (München) / Kleiner, Angélique (München) / Metz, Sebastian (München) / Potthast, Daniel (München) / Reinfandt, Lucian (Wien) / Sipl, Mari (München) / Sonego, Leonora (München) / Thomann, Johannes (Zürich) / Younes, Khaled (Sadat City) / Zinger, Oded (Jerusalem)

zusammengestellt von Andreas Kaplony, Ludwig-Maximilians-Universität München, andreas.kaplony@lmu.de

\section{A Übersicht}

Die erste Aufgabe der arabischen Papyrologie ist und bleibt die fachkundige Edition möglichst vieler unpublizierter arabischsprachiger Dokumente auf Papyrus, Pergament, Papier u.ä. Von den über 180.000 noch unpublizierten Dokumenten in arabischer oder hebräischer Schrift vor 1517 sind nun weitere 76 publiziert: aus Zentralasien 3 Briefe (8. Jh.; Nr. 51); aus Ägypten 8 Verträge (11. Jh.; Nr. 3), 15 Steuerquittungen (9. Jh.; Nr. 80; 94), 15 jüdisch-arabische Dokumente (Nr. 1; 110), 6 jüdisch-arabische Einzelstücke (Nr. 46; 47; 71; 99) und 19 weitere Einzelstücke (Nr. 21; 22; 37; 38; 41; 50; 75; 77; 78; 91; 92; 93; 95; 96; 101; 102); aus Sizilien 6 Dokumente (12. Jh.; Nr. 98); aus Spanien 1 jüdisch-arabisches (Nr. 48) und ein weiteres Stück (Nr. 69), aus dem Jemen 2 jüdisch-arabische Briefe (Nr.

\footnotetext{
Anmerkung: Die Abkürzungen folgen der Checklist of Arabic Documents (www.naher-osten. Imu.de/isap/isap_checklist) und der (Full) Arabic Papyrology Bibliography of Editions and Research (www.naher-osten.Imu.de/apb). Einen zeitnahen Überblick über Neuerscheinungen bieten die Websites der International Society for Arabic Papyrology (www.naher-osten.Imu.de/ isap) und der Münchner Forschergruppe zur arabischen Papyrologie (www.naher-osten.Imu.de/ papyrologie) sowie die Maillist der International Society (isap@listserv3.auburn.edu). - Bibliographische Hinweise und Nachträge, gerne auch (elektronische) Belegexemplare werden erbeten an andreas.kaplony@lmu.de.
} 
71; 72). ${ }^{1}$ Dazu kommt ein arabischer Brief in lateinischen Buchstaben (9. Jh.; Nr. 57). Eine Arbeit beschreibt ägyptische siǧill-Urkunden (11. Jh.; Nr. 56), eine andere 35 kleinasiatische waqf-Urkunden (14 Jh.; Nr. 5). Insgesamt geht die Arbeit so langsam voran, dass wir uns eine Doppelstrategie überlegen sollten mit schnell hergestellten, aber oberflächlichen (Nr. 90) und traditionellen gründlichen Editionen.

Bis etwa 800 und darüber hinaus haben wir in der Islamischen Ökumene neben den arabischen auch griechische, koptische und baktrische Dokumente, bei den Muslimen des nach-islamischen Spaniens haben arabische Dokumente ihre eigene Funktion (Nr. 43; 69), und arabische Formeln werden in spätere persische Dokumente eingebaut (Nr. 40). Die folgende Bibliographie erwähnt also auch Forschung zu anderssprachigen Dokumenten, soweit sie für das Verstehen der Islamischen Welt (the Islamicate World) hilfreich sind. Einen Überblick über die ganze Bandbreite der demotischen, griechischen, koptischen und arabischen Stücke gibt auch dieses Jahr das Nilus-Bändchen der Wiener Sammlung (Nr. 10; Nr. 79). Erfreulicherweise war die arabische Papyrologie auf dem 27. PapyrologenKongress in Warschau 2013 vertreten (Nr. 8; 22; 58; 91) und spielt auch in der Festschrift Gascou prominent mit (Nr. 6; Nr. 21; 38; 80).

Die zweite Aufgabe der arabischen Papyrologie ist die linguistische und historische Auswertung der genannten Dokumente. Aktuelle Forschungsfragen sind diejenige nach der Verwaltung, Wirtschaft und Arabisierung Ägyptens und Syrien-Palästinas in vorklassischer Zeit, also bis 800 (Nr. 21; 60; 63; 74; 89; 112; 122; 133), nach der Rechtspraxis, allgemein (Nr. 7; 116) und in Bezug auf die rechtliche Einbindung - wichtig hierzu der Sammelband von ECHEVARRIA, MoNFERRER-SAla und TolAn (Nr. 7) - der ägyptischen Kopten (Nr. 12; 92; 96; 100), Juden (Nr. 11; 12; 28; 62; 99) und Westeuropäer (Nr 13), der iranischen, irakischen und syrischen Christen (Nr. 86), der Baktrier (Nr. 16), der spanischen Juden und Christen (Nr. 23) und in nachislamischer Zeit der spanischen Muslime (Nr. 43; 69) und nach der Adaption von Konzepten aus dem islamischen Hegemonialdiskurs in den baktrischen (Nr. 16), den jüdischen (Nr. 1; 4; 11; 27; 110), den christlichen (Nr. 68; 73) und den regional maġribinischen (sic, Nr. 53) Sonderdiskurs. Die Forschung hat sich weiter mit der in den Dokumenten fassbaren Sprach- und Schriftrealität beschäftigt (Nr. 59; 130), mit dem Verhältnis von Dokumenten und literarischer Überlieferung (Nr. 33; 44; 56), mit der Spiegelung der materiellen Kultur und des Umgang mit Esswaren in den Dokumenten (Nr. 5; 45; 62; 67; 100; 107; 113; 123; 137) und mit Fragen von Archivierung und Verwaltungsabläufen (Nr. 24;

1 In Besprechungen älterer, nicht in dieser Bibliographie auftauchender Editionen geht es um Dokumente aus Syrien (Nr. 106; 114; 118; 121) und aus Ägypten (Nr. 108; 119; 132). 
55; 78; 83; 84). Die Freude an FRIEDMANs neuem Wörterbuch zum Jewish Documentary $\operatorname{Arabic}^{2}$ (Nr. 2) wird dadurch gedämpft, dass FRIEDMAN die arabischen Begriffe nur ins Hebräische, nicht auch ins Englische übersetzt. Bei der historischen Auswertung sind die Wissenschaft von den jüdisch-arabischen GenizaDokumenten (Nr. 1; 4; 26; 27; 110; 111; 128), die griechische Papyrologie und die Koptologie starke Schwestern der arabischen Papyrologie.

Für den historischen Vergleich ist der Verweis auf Dokumente außerhalb des genannten Rahmens sinnvoll: auf Dokumente aus Sogdien (Nr. 14); aus dem osmanischen Ägypten (15; 24; 52; 129); aus Westeuropa (31; 39); aus Iran (19. Jh.; Nr. 40; Armenier in Iran 16. Jh.: Nr. 104), aus Hwwārazm (Nr. 83; 84); aus dem Haḍramawt (Nr. 115; 126; 136) und aus Indien (Nr. 87). Besonders hervorzuheben ist eine Erkenntnis von Hanna (Nr. 52): die Zunahme von Dialektmerkmalen in den Dokumenten nach 1600 wiederspiegelt, dass eine breitere Bevölkerung Zugang zur Welt des Schreibens gewinnt. (Andreas Kaplony)

\section{B Monographien ${ }^{3}$}

1. Ackerman-Lieberman, Phillip I., The Business of Identity: Jews, Muslims, and Economic Life in Medieval Egypt, Stanford 2014 (Stanford Studies in Jewish History and Culture). - Mit der Anwendung von älterem jüdischem Recht grenzen sich die jüdischen von den nicht-jüdischen Kaufleuten ab. Die Beziehung zwischen älterem jüdischem Recht und tatsächlicher Rechtspraxis ist ausgesprochen interaktiv. In der Tat können die aus den jüdischarabischen Rechtsdokumenten gewonnenen Erkenntnisse mutatis mutandis auf die weitere Islamische Welt übertragen werden. Im Anhang die Edition, Übersetzung und Kommentar von 15 Dokumenten. (Kaplony)

2. Friedman, Mordechai A., Milon ha-'Aravit ha-Yehudit mi-yeme ha-benayim: le-te'udot ha-genizah šel Sefer Hodu u-le-țeqsțim aherim [A Dictionary of Medieval Judeo-Arabic in the India Book Letters from the Geniza and in Other Texts], Jerusalem 2016. -F.'s new dictionary is an invaluable resource for the study of Middle Arabic texts. The dictionary originated from his many years' work on the India Book and especially on the documents from the archive of

2 Zu meinem Begriff Jewish Documentary Arabic siehe Kaplony, Andreas, „Scribal Traditions in Documentary Arabic: From the One Imperial Standard Language to the One (Jewish) Language for Transnational Communication (7th-12th Centuries)“, Jewish History (= Goldberg, Jessica (Hrsg.), Documentary Geniza Research in the 21st Century) [im Druck].

3 Von den Monographien werden Nr. 2,3,4 und 5 in dieser Zeitschrift einzeln besprochen. 
Halfon ha-Levi b. Nethanel. However, F. wisely decided to expand the scope of the dictionary to include other Judeo-Arabic texts. As the dictionary is arranged according to the Hebrew alphabet and, unlike BLAU's dictionary (2006), does not provide English definitions or display the entries in Arabic script (except at the top of the page), it is clearly intended for scholars in Jewish studies. However, scholars of Arabic documents will do well to make the effort to consult this dictionary as it is focused on documentary texts and contains numerous meanings not found in any other dictionary, medieval or modern. The dictionary contains an appendix with notes on Judeo-Arabic grammar, an index of „entries and their roots“ and an index of Geniza documents divided between India Book documents and non-India Book documents. - To find out whether a given Geniza shelfmark is included in the India Book and its India Book shelfmark, one may consult the indices provided in https://genizablues.wordpress.com/2017/06/15/india-book-indices/. (Zinger)

3. Rāğib, Yūsuf, Transmission de biens, mariage et répudiations à Uqlūl, village du Fayoum au Ve/XIe siècle, Kairo 2016 ([Publications de] l’Institut français d'archéologie orientale 1125. Cahiers des Annales islamologiques 33). Edition, Übersetzung, Kommentar und einführende Analyse von acht Verträgen. Es handelt sich um einen Kaufvertrag für eine gedeckte Halle oder Passage (saqīfa) (Nr. 1), drei Kaufverträge für je einen Hof oder Garten ('arșa) (Nr. 2-4), die Bestätigung (iqrār) der Übergabe einer Wohnung (manzil) (Nr. 5) und drei Heiratsverträge (Nr. 6-8), wobei Nr. 7 auf verso einen Scheidungsvertrag der Eheleute trägt. - Bei Nr. 8 sind nicht Bräutigam und Braut Wächter (hufarä'), sondern der Vater und der Großvater der Braut. (Kaplony)

4. Russ-Fishbane, Elisha, Judaism, Sufism, and the Pietists of Medieval Egypt: A Study of Abraham Maimonides and His Times, Oxford 2015 (Oxford Studies in the Abrahamic Religions). - Eine Beschreibung des Pietismus (hasīdūt), wie ihn Maimonides, der Leiter ( $r a^{\prime}$ ’ss) der Rabbaniten Ägyptens, propagiert: eine Organisation mit von Meistern geleiteten Zirkeln und Konventen, und eine Reform der Liturgie (mit Prostration, Knien, Füßewaschen und Reihengebet) nach sufischem bzw. allgemein-muslimischen Vorbild unter Rückgriff auf einzelne älteren jüdische Anweisungen. Eigentliches Ziel ist die Wiederbelebung des Volkes Israel durch die Wiederherstellung des Prophetentums. Die Untersuchung basiert auch auf den im Original erhaltenen Briefen von Maimonides. (Kaplony)

5. Trépanier, Nicolas, Foodways and Daily Life in Medieval Anatolia: A New Social History, Austin 2014. - Eine dichte Beschreibung der Herstellung von Esswaren (Gärten, Felder, Tierhaltung) in Anatolien im 14. Jahrhundert, von Austausch (Transport, Märkte, Mühlen, Steuern, Militär), Verzehr (Kauf, Auf- 
bewahrung, Kochen, Mahlzeiten, Gerichte und Getränke, Gastfreundschaft) und mit dem Essen verbundenen religiösen Fragen (Fasten, Feste) usw. Die Untersuchung basiert auch auf Abschriften von 35 arabischen Waqf-Dokumenten. (Kaplony)

\section{Sammelwerke}

6. Derda, Tomasz / Łajtar, Adam / Urbanik, Jakub (Hrsg.), Proceedings of the 27th International Congress of Papyrology, Warsaw, 29 July - 3 August 2013, Warschau 2016 (The Journal of Juristic Papyrology Supplements 28).

7. Echevarria, Ana / Monferrer-Sala, Juan Pedro / Tolan, John V. (Hrsg.), Law and Religious Minorities in Medieval Societies: Between Theory and Praxis. De la teoría legal a la práctica en el derecho de las minoría religiosas en la Edad Media, Turnhout 2016 (Religion and Law in Medieval Christian and Muslim Societies 9).

8. Fournet, Jean-Luc / Papaconstantinou, Arietta (Hrsg.), Mélanges Jean Gascou: textes et études papyrologiques (P. Gascou), Paris 2016 (Travaux et mémoires 21,1). - Diese Festschrift enthält 88 Editionen von Papyri aus dem byzantinischen und islamischen Ägypten und 9 Aufsätze zur gleichen Thematik. Für die arabische Papyrologie sind die Editionen Nr. 24-25, 27-28, 38, 52-58, 60-62 vom besonderen Interesse; von den Aufsätzen diejenigen von Willy Clarysse und Arietta Papaconstantinou. (Berkes)

9. Łajtar, Adam / Obłuski, Artur / Zych, Iwona (Hrsg.), Aegyptus et Nubia Christiana: The Włodzimierz Godlewski Jubilee Volume on the Occasion of His 70th Birthday, Warschau 2016.

10. Palme, Bernhard (Hrsg.), Hieroglyphen und Alphabete: 2500 Jahre Unterricht im Alten Ägypten, Wien 2016 (Nilus 23). - Dieses Nilus-Bändchen begleitet die Sonderausstellung 2016 der Wiener Papyrussammlung. Beschrieben sind, neben zahlreichen Coptica aus islamischer Zeit, ein Wandverputz mit arabischer Schrift (S. 57, Abb. 24), ein hebräisch-arabisches Alphabet (Nr. 8), die Zeichnung eines Pferdes aus dem 7. Jahrhundert (Nr. 29), Schreibübungen von Buchstaben (Nr. 38) und Formeln (Nr. 39, 46, 47, 48) neben griechischem bzw. koptischem Text, ein Stück aus der Biographie von Muhammad in Alltagsschrift (Nr. 40) und aus Mālik's Muwațța' in Buchschrift (Nr. 41), ein Protokoll (Nr. 61), Zahlzeichen (Nr. 62), eine Divisionstabelle (Nr. 63) und zwei Tafeln mit Koransuren (Nr. 74, 75). (Kaplony) 


\section{Artikel}

11. Ackerman-Lieberman, Phillip I., „Arabic Legal Terminology in JudaeoArabic: Loanwords or Loan Shifts?“, Jerusalem Studies in Arabic and Islam 43 (2016): 1-10. - Arabische Begriffe des islamischen Rechts behalten beim Transfer in den jüdischen Kontext nicht einfach die Bedeutung (so qirāọ „Commenda“ ohne Risiko für den stillen Teilhaber), sondern vertreten gleichzeitig die leicht anderen Begriffe des jüdischen Rechts (so qirā Wiedergabe von aramäisch 'isqā, hebräisch 'eseq mit Risiko für den stillen Teilhaber). Um ein Missverständnis vor islamischem Gericht zu vermeiden, wird disambiguiert (als qirạ̣̄ al-gōyīm). (Kaplony)

12. Adang, Camilla, „Swearing by the Mujaljala: A Fatwā on Dimmī Oaths in the Islamic West“, in: Echevarria, Ana et al. (Hrsg.), Law and Religious Minorities in Medieval Societies ..., Turnhout 2016, 160-172. - A fatwa from al-Wansharīsī's Mi 'yār about where an oath must be sweared stresses that oaths should be pronounced in a place where God is exalted. Accepting as valid the oath of non-Muslims in their temple, by that which they hold sacred (such as the Torah), reflects the recognition of the religion of the others. (Daga Portillo)

13. Apellániz Ruiz de Galarreta, Fancisco Javier, „Judging the Franks: Proof, Justice, and Diversity in Late Medieval Alexandria and Damascus“, Comparative Studies in Society and History 58 (2016): 350-378. - This article challenges the view that in the Mamlūk ports Muslims and Frankish merchants had distinct legal systems. Instead, a hybrid system combining Latin and Islamic practices (based on the siyāsa shariyya) and crossing communal borders developed since the middle of the 14th century. (Potthast)

14. Ashurov, Barakatullo, „Sogdian Christian Texts: Socio-Cultural Observations“, Archiv Orientální 93 (2015): 53-70. - Überblick über die in den Ruinen von Shüipang, $10 \mathrm{~km}$ nördlich von Turfan in China gefundenen sogdischen Texte christlichen Inhalts. Es sind in sogdischen Dokumenten zwei Schriften gebräuchlich: eine modifizierte syrisch-aramäische und eine eigene sogdische. Christliche sogdische Texte sind erkennbar an der Verwendung der ersteren. Die Studie behandelt Orthographie, Sprachgebrauch sowie das Verhältnis von Dokument und Text in dieser wichtigen Gruppe von Schriftträgern. (Reinfandt)

15. Ayoub, Samy, „'The Sultan Says': State Authority in the Late Hanafī Tradition“, Islamic Law and Society 23 (2016): 239-248. - This analysis of 17th-18th century Hanafī works shows the incorporation of state orders within Hanafī legal discourse. A. challenges Hallaq's and Abou-l-Faḍl's view that Islamic law is epistemically divorced from political authority. Concrete examples show the relation of siyāsa and $\operatorname{sharī}^{`} a$. (Daga Portillo) 
16. Azad, Arezou, „Living Happily Ever After: Fraternal Polyandry, Taxes and 'the Houses' in Early Islamic Bactria“, Bulletin of the School of Oriental and African Studies 79 (2016): 33-56. - Untersuchung über den Einfluss des kulturell entstehenden und sich territorial ausbreitenden Islams des 2./8. Jahrhunderts auf die soziale Praxis, insbesondere das Heiratsverhalten alteingesessener Familien in den eroberten Gebieten. Konkret geht es um das am äußeren östlichen Rand des umayyadischen und dann abbasidischen Herrschaftsgebiets liegenden Baktrien (im heutigen nördlichen Afghanistan). Die Wahl der Region ergibt sich aus der vergleichsweise guten Quellenlage: von hier stammt jener einzigartige Fund von Rechtsdokumenten auf Leder auf baktrisch oder arabisch, die mit dem Zeitraum vom 4.-8. Jahrhundert n. Chr. neben anderen Übergangszeiten eben auch jene hin zum Islam dokumentieren. - A. zeigt, wie bei der Etablierung muslimischer Herrschaft die alteingesessene baktrische und eine neue islamische Verwaltungspraxis nebeneinander zur Anwendung kommen, wie aber auf lange Sicht das neue abbasidische Besteuerungssystem die in jener Region traditionell gepflegte Polyandrie mehr aus Zweckdienlichkeit denn aus Intention obsolet macht und verschwinden lässt. (Reinfandt)

17. Berkes, Lajos, „Schreibübungen mit einem Psalm-Zitat: Neues aus der Verwaltung des Fayums im 8. Jh.”, Zeitschrift für Papyrologie und Epigraphik 188 (2014): 241-244. - Edition des griechischen Papyrus P. Heid.inv. G 2861 verso (2./8. Jh.). Es handelt sich um eine Schreibübung von Einträgen in Steuerregister, wie sie im Steuerbüro des fayyumischen Distriktvorstehers (Pagarchen) vorgenommen und in arabischen, griechischen und koptischen Papyri zahlreich, bisweilen sogar mehrsprachig auf ein und demselben Blatt belegt sind. Hier handelt es sich um die Schreibübung eines griechischen Steuerregisters, die auf der Rückseite eines wiederverwendeten arabischen Textes (genauer: eines Briefes mit möglicherweise amtlichem Hintergrund) unternommen worden war. (Reinfandt)]

18. Berkes, Lajos / Haug, Brendan, „Villages, Requisitions, and Tax Districts: Two Greek Lists From the Eighth-Century Fayyūm“, Bulletin of the American Society of Papyrologists 53 (2016): 189-222. - Edition zweier griechischer Steuerlisten (P. CtYBR inv. 379 und 461). Im 2./8. Jahrhundert ausgestellt, stammen sie aus dem Büro des Distriktvorstehers (Pagarchen) des Fayyum und untergliedern das Gebiet des südwestlichen Fayyum in steuerzahlende Einheiten von Dorfgröße (griech. choria). (Reinfandt)

19. Blouin, Katherine, „Papyri in Paris: The Greek Papyrus Collection in the Bibliothèque Nationale de France“, in: Derda, Tomasz et al. (Hrsg.), Proceedings of the 27th International Congress of Papyrology ..., Warschau 2016, 853-881. - Zur Geschichte der Sammlung, ihrer Zusammensetzung und zur 
laufenden Katalogisierung. Erwähnt werden die arabischen Dokumente BnF Arabe 4633, 4634, 4635 (S. 858), Suppl.gr. 1384.7.3, 1384.11.3 und 1384.21.5 (S. 875). (Kaplony)

20. Boud'hors, Anne, „Apprendre à lire et à écrire: deux documents coptes revisitées“, in: Derda, Tomasz et al. (Hrsg.), Proceedings of the 27th International Congress of Papyrology ..., Warschau 2016, 1027-1039. - Zwei koptische Bestätigungen eines Vaters (BnF MMA 1895, 1894) aus dem 7.-8. Jahrhundert, dass der Sohn, anders als mit einem Lehrer vereinbart, schon selber lesen und schreiben gelernt hat. (Kaplony)

21. Boud'hors, Anne, „Degrès d'arabisation dans l'Egypte du viiie siècle: CPR II 228 revisitée ...“, in: Fournet, Jean-Luc / Papaconstantinou, Arietta (Hrsg.), Mélanges Jean Gascou ..., Paris 2016, 71-90. - Edition, translation, and study of P. Vindob. K803 (= CPR II 228), a Coptic business letter, possibly from the 8th century. This is a unique example of a bilingual address, Coptic and Arabic. No diacritics, as characteristic for Coptic Fayyūmī documents. Analysis of the language reveals a non-homogeneous society. The document possibly was written by a convert. (Daga Portillo)

22. Bsees, Ursula, „Half a Sale Contract or an Unknown Type of Document? Going Deeper Into P. Cair.EgLib. inv. 885 verso“, in: Derda, Tomasz et al. (Hrsg.), Proceedings of the 27th International Congress of Papyrology ..., Warschau 2016, 1077-1084. - Edition of a contract of sale of a vineyard. Because of the unusual formulae, the scribe possibly was a notary who wrote it down in his personal register. This shows a notary's daily work. (Sipl)

23. Bueno, Marisa, „Los vapores de la sospecha. El bano público entre el mundo andalusí y la Castilla medieval (siglos X-XIII)“, in: Echevarria, Ana et al. (Hrsg.), Law and Religious Minorities in Medieval Societies ..., Turnhout 2016, 125-156. - This study deals with the variety of the functions of baths, the legislation regarding the segregation of sexes and of religious communities (Jews, Muslims, and Christians) in al-Andalus and Castilla, and the causes that led to closing the baths in the 16th century. The study exhaustively uses Arabic sources and Fueros. (Daga Portillo)

24. Burak, Guy, „Evidentiary Truth Claims, Imperial Registers, and the Ottoman Archive Contending Legal Views of Archival and Record-Keeping Practices in Ottoman Greater Syria (Seventeenth-Nineteenth Centuries)“, Bulletin of the School of Oriental and African Studies 79 (2016): 233-254. - This is about a debate among Hanafĩ jurists of Ottoman Syria as to whether to use Ottoman imperial registers as independent evidence. For this purpose, B. examines, e. g., the views of the Hanafī jurist al-Hașkafī (d. 1677) on the subject. (Metz)

25. Calament, Florence, „Coup de projecteur sur un document copte des archives du monastère Saint-Jérémie de Saqqara: P. RevilloutCopt. 3 (P. Louvre 
N 2405/5)“, in: Fournet, Jean-Luc / Papaconstantinou, Arietta (Hrsg.), Mélanges Jean Gascou ..., Paris 2016, 91-100.

26. Chakravarti, Ranabir, „Indian Trade through Jewish Geniza Letters (1000-1300)“, Studies in People’s History 2 (2015): 27-40. - Ein Überblick über die wichtigsten Referenzwerke und die Quellenkorpora, dann die Waren, die aus Indien (Betelnuss (fawfal, von Sanskrit pugaphala), Kardamon, Pfeffer, Zimt, Kampfer, Lack, lalas/lanas-Kleider, Eisen, Goldmünzen, Silber, Kupfer) und nach Indien gebracht wurden; abschließend Beispiele zu Geschäftspartnerschaften, zu Übergriffen von Herrschern, und zu persönlichen Beziehungen, auch zur Zusammenarbeit jüdischer, muslimischer und indischer Kaufleute. (Kaplony)

27. Cohen, Mark R., „The ,Custom of the Merchants“ in Gaonic Jurisprudence and in Maimonides' Mishneh Torah“, in: Schapkow, Carsten / Shepkaru, Shmuel / Levenson, Alan T. (Hrsg.), The Festschrift Darkhei Noam: The Jews of Arab Lands, Leiden 2015 (Brill's Series in Jewish Studies), 86-111.

28. Cohen, Mark R., „Defending Jewish Judicial Autonomy in the Islamic Middle Ages“, in: Echevarria, Ana et al. (Hrsg.), Law and Religious Minorities in Medieval Societies ..., Turnhout 2016, 13-33. - Jews relied on Islamic judiciary especially for commercial issues. Muslim and Jewish judges cooperated, and Muslim jurists considered non-Muslim courts part of the system. To preserve judicial autonomy, commercial laws were included in the Halakha. (Daga Portillo)

29. Clarysse, Willy, „Kosmas and Damianus in Egyptian Onomastics“, in: Fournet, Jean-Luc / Papaconstantinou, Arietta (Hrsg.), Mélanges Jean Gascou ..., Paris 2016, 559-564.

30. Cromwell, Jennifer, „Identifying New Scribes in Old Documents: P. KRU 34 and 55“, Enchoria 34 (2014-2015): 49-65; Tff. 7-9. - Neuedition zweier koptischer Papyri aus London (P. KRU 34 und 55), an denen C. exemplarisch das Potential dieser spezifischen Dokumente aufzeigt, von denen es noch erheblich mehr gibt. Beide Papyri stammen aus Djeme (Medinet Habu), dem Hauptort der oberägyptischen Region Theben, und wurden im 1.-2./7.-8. Jahrhundert geschrieben. Zur Fülle des Materials kommt der glückliche Umstand hinzu, dass viele der Dokumente von den Schreibern selbst signiert sind, wie auch im vorliegenden Fall, wodurch eine Rekonstruktion der Schreibernamen möglich wird. - Die Neuedition vor dem Hintergrund eines besseren Wissensstands erlaubt die Rekonstruktion der Arbeitsverhältnisse koptischer Schreiber in diesem Umfeld während der Zeit der schrittweisen Entstehung islamischer Gesellschaften nach der arabischen Eroberung. (Reinfandt)

31. D'Ottone Rambach, Arianna, „Arabic Seals and Scripts: Simone Assemani through His Unpublished Correspondence“, in: Callegher, Bruno / D’Ottone 
Rambach, Arianna (Hrsg.), 4th Simone Assemani Symposion. Trieste, 26-27 September 2014, Trieste 2015 (Polymnia. Numismatica antica e medievale. Studi 9), 17-36. - Starting from an Arabic letter by Simone Assemani (1752-1821) to a German colleague, the article mentions, e.g., the European knowledge of Arabic scripts in the 18th century, the exchange of Islamic objects in Orientalist circles, and Islamic spolia in medieval art. (Potthast)

32. D’Ottone, Arianna, „Arabic Palaeography“, in: Bausi, Alessandro et al. (Hrsg.), Comparative Oriental Manuscript Studies: An Introduction, Hamburg 2015, 271-276.

33. Dekkiche, Malika, „The Letter and Its Response: The Exchanges between the Qara Qoyunlu and the Mamluk Sultan: Ms Arabe 4440 (BnF, Paris)“, in: Arabica 63 (2016): 579-626. - Eine diplomatische Untersuchung der in BnF Arabe 4440 erhaltenen Abschriften der arabischen Briefe zwischen dem Qara Qoyunlu-Gouverneur Pīr Būdāq (gest. 870/1466) und dem mamlūkischen Sultan Īnāl (reg. 857-864/1453-1461). Bestimmend ist der Unterschied im Sozialstatus zwischen Absender und Empfänger. Behandelt werden Struktur, Themen, Sprache, Stil und (Koran-)Zitate. Im Anhang die Edition der Briefe 36, 37, 38 und 40. (Kaplony)

34. Delattre, Alain / Pilette, Perrine / Vanthieghem, Naïm, „Papyrus coptes de la Pierpoint Morgan Library I: cinq documents du monastère de Baouît“, Journal of Coptic Studies 17 (2015): 33-53. - (Teils Neu-)Edition von fünf koptischen Papyri des 7.-8. Jahrhunderts aus dem Apa Apollos-Kloster in Bawit. Nr. 1-2 sind die Quittung bzw. Anweisung eines Klostervorstehers, Nr. 3 enthält einen Brief, Nr. 4 (Verso von Nr. 3) ist eine Abrechnung über Wein und Nr. 5 enthält eine Liste von Personen. (Berkes)

35. Delattre, Alain / Vanthieghem, Naïm, „Sept reçus de taxe thébains du VIIIe siècle“, Journal of Coptic Studies 16 (2014): 89-102. - Edition von sieben koptischen Steuerquittungen aus den 720-er bzw. 730-er Jahren aus der thebanischen Region. Es werden Zahlungen für die Kopfsteuer, die Aufwandsteuer (dapane) und die Aufwandsteuer des Statthalters quittiert. (Berkes)

36. Delattre, Alain / Vanthieghem, Naïm, „Trois ostraca coptes de Hambourg“, Journal of Coptic Studies 16 (2014): 103-113. - Edition von drei koptischen Ostraka des 7.-8. Jahrhunderts aus der thebanischen Region. Nr. 1 ist ein Gebet, Nr. 2 enthält eine Quittung und Nr. 3 ist ein neuer Brief von dem wohlbekannten Mönch Frange. (Berkes)

37. Delattre, Alain / Vanthieghem, Naïm, „Les trois colophons de l'Evangile de Jean découvert à Naqlūn“, in: Łajtar, A. et al. (Hrsg.), Aegyptus et Nubia Christiana ..., Warschau 2016, 61-72. - This paper presents the edition of two Coptic colophons and an Arabic note written at the end of the 11th-12th century manuscript of the Gospel of John found in 2002 in the Naqlūn cemetery. 
D. and V. argue that the Gospel in discussion was the property of the deacon Shenoute son of John, who was presumably buried in this cemetery. (Younes)

38. Delattre, Alain / Vanthieghem, Naïm, „Un ensemble archivistique trilingue à Strasbourg: un protocole et deux ordres de réquisition de la fin du VIIe siècle“, in: Fournet, Jean-Luc / Papaconstantinou, Arietta (Hrsg.), Mélanges Jean Gascou ..., Paris 2016, 109-131. - Edition, discussion, and plates of a bilingual Arabic-Greek entagion of the governor 'Abd al-'Azīz b. Marwān, headed by an Arabic-Greek protocol (P. Stras. inv. arab. 366 A; 694-695; Antinoé?) and of a Coptic entagion (with Greek introductory formula and address) issued by the dux Flavius Atias 'Ațiya b. Dju'ayd (P. Stras. inv. arab. 366 B; 695?; Antinoé ?). (Garosi)

39. Diem, Werner, „Ägyptisch-Arabisch im 17. Jahrhundert: die arabischen Zeugenaussagen in Mordechai ha-Levis Sefer Darke no'am (Venedig 1697)“, Mediterranean Language Review 21 (2014): 1-90.

40. Diem, Werner, „,Zur besten Zeit und schönsten Stunde‘. Ein Beitrag zur Kenntnis persischer Eheverträge der Qāḡārenzeit“, Zeitschrift der Deutschen Morgenländischen Gesellschaft 166 (2016): 101-140. - Analyse von 42 Eheverträgen aus dem qāğārischen Iran (1779-1924), dazu einem früheren und drei späteren Eheverträgen (1750 bzw. 1926-1929). Die Verträge haben zahlreiche arabische Formeln; D. verweist jeweils auf Parallelen in früheren arabischen Eheverträgen. Der Zeitpunkt der Eheschließung hat wohl einen astrologischen Hintergrund. Im Anhang die Edition, Übersetzung und Kommentar von BSB, Cod.pers. 502 (1890). (Kaplony)

41. Dridi, Moez, „La fonction du 'akkām dans la caravane des pèlerins: un métier méconnu, à la lumière d'un document légal mamelouk inédit“, Arabica 63 (2016): 89-117. - A call-to-witness whereby a man surnamed „the Watercarrier" (al-saqqā') takes on the obligation to follow a pilgrim from Cairo to Mecca and back as a kind of personal servant. The text reveals the existence of established customs in this field, although this is the only preserved contract of this kind. D. discusses the institutionalization of professions related to the hadjdj and their taxation in Damascus and Cairo. (Sonego)

42. Dzierzbicka, Dorota, „Wine Consumption and Usage in Egypt's Monastic Communities (6th-8th c.)“, in: Łajtar, A. et al. (Hrsg.), Aegyptus et Nubia Christiana ..., Warschau 2016, 99-111.

43. Echevarria, Ana, „Cadies, alfaquíes y la transmisión de la sharī'a en época mudejar“, in: Echevarria, Ana et al. (Hrsg.), Law and Religious Minorities in Medieval Societies ..., Turnhout 2016, 47-71. - The Mudejars kept Islamic law after the 11th century. Christian rulers elected qādīs to impart justice to Muslims. Translations were done from Arabic, such as the Leyes de Moros, the Llibre de la sunna e xara de los Moros, and the Breviario sunni (14-15th 
century). The abolition of the hudūd took place among the Mudejars and lateron in the kingdom of Granada. (Daga Portillo)

44. El Shamsy, Ahmed, „Debates on Prayer in Second/Eighth-Century Islam: Some Remarks on Sijpesteijn's Papyrus“, Journal of Near Eastern Studies 75 (2016): 335-337. - A response to Sijpesteijn, „Hadith Fragment“ (2015). The fragment was used by students to practice knowledge of rituals. Koranic recitation in prayers was not disputed, nor is a change in legal doctrine proved by the hadith. EL SHAmsy argues from a retrospective perspective based on the praxis of classical jurists dealing with forgetful recitations. (Daga Portillo)

45. Fournet, Jean-Luc / Russo, Simona, „La culture matérielle dans les papyrus: une nouvelle entreprise lexicographique“, in: Derda, Tomasz et al. (Hrsg.), Proceedings of the 27th International Congress of Papyrology ..., Warschau 2016, 1393-1413. - Die eigentliche Herausforderung besteht in der Verbindung der (meist namenlosen) archäologischen Funde mit den (meist objektlosen) Bezeichnungen in den Texten. F. und R. wollen die arabischen Bezeichnungen mit einbeziehen. (Kaplony)

46. Friedman, Mordechai A., „Teluna la-sulțān 'al r(abbi) Abraham ben haRambam“ [A Complaint to the Sultan against Abraham Maimonides], Zion 81 (2016): 335-390.

47. Friedman, Mordechai A., „'Edut ḥadašah 'al bițț̣l ha-tefilot v-minḥage hatefilat ha-Eretz Yisra'eliyim be-Mișrayim b-ime ha-Ra'abam“ [New Evidence of the Abolition of Eretz-Israel Prayers and Prayer Rituals in Egypt in Abraham Maimonides' Times], in: Ehrlich, Uri (Hrsg.), Jewish Prayer: New Perspectives, Beersheba 2016 (The Goldstein-Goren Library of Jewish Thought 20), 315-326. -First, F. reviews the evidence for the successful struggle to abolish the Palestinian prayer customs in Egypt during the reign of Abraham Maimonides. He then turns to examine (and publish) a new piece of evidence: a fragment of a draft of a public announcement declaring the Palestinian prayer customs unacceptable and therefore abolishing them. (Zinger)

48. Friedman, Mordechai A., „An India Trader's Partnership in Almería (1139)“, Sefarad 76 (2016): 75-96. - Edition, translation, and study of Judeo-Arabic fragments CUL Or.1080 1.88.26.2 and TS NS 99.55.13. This is the oldest legal document from Almeria (1139). The partnership deed of a merchant-scholar associated with Judah ha-Levi sheds light on trade routes. (Daga Portillo)

49. Gebhardt, Marius, „Die Berliner Papyrusdatenbank (BerlPap)“, in: Derda, Tomasz et al. (Hrsg.), Proceedings of the 27th International Congress of Papyrology ..., Warschau 2016, 1387-1391. - Eine kurze Beschreibung. (Kaplony)

50. Gruber, Christiane, „From Prayer to Protection: Amulets and Talismans in the Islamic World“, in: Leoni, Francesca (Hrsg.), Power and Protection: Islamic Art and the Supernatural, Oxford 2016 (Ashmolean Museum), 33-51. - 
Amulets and talismans in different materials are discussed, e.g., a painted scroll (Oxford, Ms. Arch.Seld.A.72.6) and a printed amulet with box (Toronto, AKM 508). The objects are presented as purely Islamic. No references to Indian or Chinese origins of their techniques and designs are made. (Thomann)

51. Haim, Ofir / Shenkar, Michael / Kurbanov, Sharof, „The Earliest Arabic Documents Written on Paper: Three Letters from Sanjar-Shah (Tajikistan). (With an Appendix by Anna-Grethe Rischel and Michelle Taube, National Museum of Denmark)“, Jerusalem Studies in Arabic and Islam 43 (2016): 141-189. - Edition of seven paper fragments found in Tajikistan in 2008, dated to the second half of the 8th century. Interesting historical review of the region with impressive macro- and microscopic observations on the paper. (Sipl)

52. Hanna, Nelly, „Seventeenth- and Eighteenth-Century Texts: Colloquial in Language, Scholarly in Form“, in: Hanna, Nelly, Ottoman Egypt and the Emergence of the Modern World 1500-1800, Kairo / New York 2014, 31-66. Der Aufsatz liegt zeitlich außerhalb unseres Rahmens, hat aber für die arabische Papyrologie wichtige Implikationen. Dass um 1600 Dialektmerkmale in arabischen Quellen häufig werden, spiegelt, wie eine breitere Bevölkerung Zugang zur Welt des Schreibens gewinnt. Dass diese Merkmale um 1900 zugunsten des Modern Standard Arabic abnehmen, zeigt den starken Einfluss der neuen Staaten und ihrer panarabischen Agenda auf das Zeitungswesen. Was bedeutet dann, wenn sich gegenwärtig in Ägypten der Dialekt als zweite Schriftsprache etabliert? (Kaplony)

53. Hendrickson, Jocelyn, „Prohibiting the Pilgrimage: Politics and Fiction in Mālikī fatwās“, Islamic Law and Society 23 (2016): 161-238. - Fatwas mirror political reality, yet mask concrete political concerns. Djihād became a more important duty than hadjdj because resources and loyalties were needed in the country, as in the case of the Maghrib. The appendix lists fatwas and their commentaries from the 11th to the 19th centuries. (Daga Portillo)

54. Hickey, Todd M., „Three Late Antique Descripta from P. Amh. II“, in: Fournet, Jean-Luc / Papaconstantinou, Arietta (Hrsg.), Mélanges Jean Gascou ..., Paris 2016, 233-242.

55. Hirschler, Konrad, „From Archive to Archival Practices: Rethinking the Preservation of Mamluk Administrative Documents“, Journal of the American Oriental Society 136 (2016): 1-28. - H. convincingly shows that we have to rethink the administrative handling of documents, focus on the archives of individual secretaries and the „small-scale administration“, and move away from the central bureaucracy of the Mamlūk empire. (Metz)

56. Horváth, Máté, „The Sijill Documents as Sources for Fatimid History during Badr al-Jamālī’s Vizierate (466/1074-487/1094)“, in: Hämeen-Anttila, Jaakko / 
Koskikallio, Petteri / Lindstedt, Ilkka (Hrsg.), Contacts and Interaction: Proceedings of the 27th Congress of the Union Européenne des Arabisants et Islamisants, Helsinki 2014, Löwen / Paris / Bristol 2017 (Orientalia Lovaniensia Analecta 254), 185-196.

57. Internullo, Dario, „Un unicum per la storia della cultura: su un papiro latinoarabo della British Library (P. Lond. inv. 3124)“, Mélanges de l'Ecole française de Rome - Moyen Âge 128,2 (2016): 1-8. - Presentation and preliminary discussion of P. Lond. inv. 3124, a 9th-century Arabic private letter written in the Latin script sent by Sati to Iohannes and headed by a Latin salutation. The letter, which is the only known example of its kind, mentions Jerusalem and a third person named Constantine. (Garosi)

58. Kaimio, Jorma, „The Division of Landed Property in P. Petra 17“, in: Derda, Tomasz et al. (Hrsg.), Proceedings of the 27th International Congress of Papyrology ..., Warschau 2016, 2025-2036. - Inhaltliche Untersuchung eines in Koenen et al., P. Petra II (2013) publizierten griechischen Papyrus. Bei diesem mit 232 erhaltenen Zeilen außerordentlich langen und in zahlreichen Einzelfragmenten erhaltenen Dokument handelt es sich um eine Erbschaftsurkunde, mit der die Aufteilung eines mütterlicherseits vermachten Vermögens von Agrarland, Wohngebäuden sowie zwei Ehepaaren im Sklavenstatus unter drei erbberechtigten Brüdern geregelt wird. Das Dokument wurde im frühen 6. Jahrhundert geschrieben und stammt aus Petra, der auf dem Gebiet des heutigen Jordanien gelegenen alten Hauptstadt der römischen Provinz Palästina III. Damit fällt es in die vorislamische Epoche, ist aber auch für die islamhistorische Forschung relevant aus Gründen der kulturellen und sprachlichen Kontinuität eines aus der Spätantike heraus geborenen Islams. Die Aufteilung des Erbvermögens geschieht mit dem Rechtsmittel des Losverfahrens, welches bis in islamische Zeit hinein Anwendung fand und in seiner Kontinuität untersucht worden ist (CROne, Patricia / Silverstein, Adam, „The Ancient Near East and Islam: The Case of Lot-Casting“, Journal of Semitic Studies 55 (2010): 423-433). (Reinfandt)

59. Kaplony, Andreas, „The Orthography and Pronunciation of Arabic Names and Terms in the Greek Petra, Nessana, Qurra and Senouthios Letters (Sixth to Eighth Centuries CE)“, Mediterranean Language Review 22 (2015): 1-81. Based on a glossary (p. 13-77) deviations from the later standard were: $\langle\underline{t}\rangle$ was pronounced as [th] or [t], $\langle\check{\mathrm{g}}\rangle$ as $[\mathrm{g}],\langle\mathrm{h}\rangle$ as $\left[\mathrm{k}^{\mathrm{h}}\right]$ or $[\mathrm{h}]$, and $\langle\mathrm{f}\rangle$ as $\left[\mathrm{p}^{\mathrm{h}}\right]$ or $[\mathrm{f}]$. The name of the prophet $\langle\mathrm{mhm} \mathrm{m}\rangle$ possibly was pronounced as [Mahmid]. The Greek orthography of Arabic influenced the Arabic orthography of Arabic. (Thomann)

60. Kaplony, Andreas, „Die Arabisierung der frühislamischen Verwaltung Syrien-Palästinas und Ägyptens im Spiegel der zweisprachigen griechisch- 
arabischen Dokumente (550-750): ein Plädoyer für einen regionalen Ansatz“, in: Schmidt, Nora / Schmid, Nora K. / Neuwirth, Angelika (Hrsg.), Denkraum Spätantike: Reflexionen von Antiken im Umfeld des Koran, Wiesbaden 2016 (Episteme in Bewegung 5), 387-404. - Papyri give a picture of regional linguistic, religious variety and identity: Harrān with its Aramaic-Arabic population and the Greek administration of Nessana near Gaza underwent a faster Arabization than Egypt. The regional pattern can also be applied to the Koran and to the first 150 years of Arab history. (Daga Portillo)

61. Labarta, Ana, „Sellos en la documentación nazarí“, Revista del CEHGR [Centro de Estudios Históricos de Granada y su Reino] 28 (2016): 129-149. L. gathers the signs of corroborations in Nașrids letters and peace contracts from the late 12th until the Spanish conquest in 1492. The seals of the Nașrid kings and of their wazìrs are read and their development is shown in a chronological order. (Potthast)

62. Lambourn, Elizabeth / Ackerman-Lieberman, Phillip I., „Chinese Porcelain and the Material Taxonomies of Medieval Rabbinic Law: Encounters with Disruptive Substances in Twelfth Century Yemen”, Legal Worlds and Legal Encounters 2 (2016): 199-238. - Ein jüdisch-arabischer Brief (1135, Aden) bittet um die rechtliche Beurteilung von șīni-Gefässen. Chinesisches șin̄i „Porzellan“ findet sich im Orient ab dem 9. Jahrhundert, hier geht es aber wohl um grünweißes qinbai-Porzellan, das, weil durchscheinend und versintert, neu in die jüdischen Reinheitskategorien eingepasst werden musste. (Kaplony)

63. Legendre, Marie, „Neither Byzantine nor Islamic? The Duke of the Thebaid and the Formation of the Umayyad State“, Historical Research 89/243 (2016): 3-18. - After the Islamic conquest of Egypt, the former Byzantine territorial system operated in parallel to the Islamic provincial system. In this time of transition, the office of the duke of the Thebaid functioned as intermediary in fiscal and civic matters between the governor and the pagarchs. Administrative reforms in the 660s-670s redefined the duke's jurisdiction by merging the Thebaid and Arcadia. The office disappeared in the early 8th century due to the increasing presence of the central administration of al-Fusțāt in the countryside. (Garosi)

64. Maurer, Karin / Tost, Sven, „Polizeiliche Erzwingungs- und Verwaltungsstäbe im spätantiken Ägypten“, in: Derda, Tomasz et al. (Hrsg.), Proceedings of the 27th International Congress of Papyrology ..., Warschau 2016, 1825-1841. - Die Untersuchung deckt die griechischen Dokumente bis ins 8. Jahrhundert ab. (Kaplony)

65. Melammed, Renée Levine, “A Look at Women's Lives in Cairo Geniza Society”, in: Schapkow, Carsten / Shepkaru, Shmuel / Levenson, Alan T. 
(Hrsg.), The Festschrift Darkhei Noam: The Jews of Arab Lands, Leiden 2015 (Brill's Series in Jewish Studies), 64-85.

66. Menci, Giovanna, "Oggetti iscritti appartenenti alla collezione dell'Istituto Papirilogico, G.Vitelli'“, in: Derda, Tomasz et al. (Hrsg.), Proceedings of the 27th International Congress of Papyrology ..., Warschau 2016, 1519-1531. Erwähnt und abgebildet wird auch ein Teil eines arabischen Glasgewichts (1529-1530). (Kaplony)

67. Mirza, Sarah Z., „The Peoples' Hadith: Evidence for Popular Tradition on Hadith as Physical Object in the First Centuries of Islam“, Arabica 63 (2016): 30-63. - Objects touched by the Prophet were considered „hadith objects“. Found by hands of Bedouins and by non-Muslims, they served to confirm the status of individuals or locations and were used as legal evidence for claims on property and exemption of taxes. (Daga Portillo)

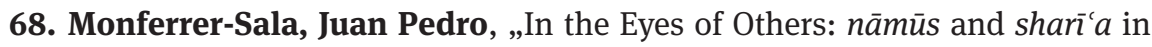
Christian Arab Authors: Some Preliminary Details for a Typological Study“, in: Echevarria, Ana et al. (Hrsg.), Law and Religious Minorities in Medieval Societies ..., Turnhout 2016, 111-124. - Nāmūs is used in the Gospels and by Christian authors for the divine law, the natural law, God's commandments, laws, and custom, while in Early Islam, the term is used for the Archangel Gabriel as mediator of revelation, or for the Torah, as by Waraqa b.Nawfal. Apocalypse also uses the word shari`‘ . (Daga Portillo)

69. Moreno, Yolanda, „La interacción en el Espacio de dos sociedades diferentes: concordia establecida entre el bachiller Hernando Alonso y la Aljama de Moros de Talavera“, in: Echevarria, Ana et al. (Hrsg.), Law and Religious Minorities in Medieval Societies ..., Turnhout 2016, 211-228. - The Letter of Archivo Colegiata de Santa Maria (1471) tells of an agreement regarding the median walls between the Aljama and a hospital built by Hernando Alonso. The problem between the Church and the Mudejars depending on the crown was solved by an agreement, not by recourse to the law. (Daga Portillo)

70. Ochała, Grzegorz, „Multilingualism in Christian Nubia: A Case Study of the Monastery of Ghazali (Wabi Abu Dom, Sudan)“, in: Derda, Tomasz et al. (Hrsg.), Proceedings of the 27th International Congress of Papyrology ..., Warschau 2016, 1265-1283. - O. schließt die zahlreichen arabischen Quellen a priori aus, da sie (abgesehen von den Grabsteinen) meist schlecht ediert sind (S. 1268). - Zu nennen wären sicher die Dokumente aus Qașr Ibrīm. (Kaplony)

71. Outhwaite, Ben / Ashur, Amir, „Between Egypt and Yemen in the Cairo Genizah“, Journal of Islamic Manuscripts 5 (2014): 198-219. - A. and O. publish two Geniza documents pertaining to the relations between Egypt and Yemen in the 12th century. The first is an 1133 Hebrew letter from Aden to Fustat 
reporting the failure of the writer to raise funds for the Jewish center in Egypt. The second is a Judeo-Arabic legal document in which a trader intending to travel to Yemen arranges for the financial security of his household (wife, two daughters, and a domestic female slave) before his departure. In the conclusion, they highlight the importance of Geniza documents to the study of medieval Yemen and its role in the Indian Ocean trade and stress that many documents await to be discovered and examined by future researchers. (Zinger)

72. Outhwaite, Ben / Ashur, Amir, „An Eleventh-Century Pledge of Allegiance to Egypt from the Jewish Community of Yemen“, Chroniques du Manuscrit au Yémen 22 (2016): 34-48. - O. and A. publish a Hebrew Geniza letter from Dū Gibla in Yemen to Fustat from around 1095. The letter declares the allegiance of the Jewish community to Mevorakh b. Sa'adya following his recent reappointment as Head of the Jews in the Fatimid Empire. The authors place the letter in the context of the shift of the traditional orientation and allegiance of the Yemeni Jewish communities from the Jewish centers in Iraq to the newly emerging center in Egypt. (Zinger)

73. Pahlitzsch, Johannes, „The Melkites and Their Law: Between Autonomy and Assimilation“, in: Echevarria, Ana et al. (Hrsg.), Law and Religious Minorities in Medieval Societies ..., Turnhout 2016, 35-46. - The Melkite legal system developed in two phases: first, the compilation of apostolic canons, synods, and councils (8th century), then the inclusion of civil law based on Procheiros Nomos' Syrian-Roman Law and a turn towards Byzance. This development was due to the expectations of Muslim rulers as to how Dhimmì legal autonomy should work. (Daga Portillo)

74. Papaconstantinou, Arietta, „Credit, Debt and Dependence in Early Islamic Egypt“, in: Fournet, Jean-Luc / Papaconstantinou, Arietta (Hrsg.), Mélanges Jean Gascou ..., Paris 2016, 613-642. - Based on a corpus of about 400 papyri and ostraca, mainly in Coptic, post-dating the Arab conquest, from Egypt and Nessana, the author analyses the social status of lenders and borrowers (as far as documented) and describes transfer of debt through guarantors and agents, as well as seasonal flows of money between town and village. About $9 \%$ of the lenders are female. (Sonego)

75. Pilette, Perrine / Vanthieghem, Naïm, „Un nouveau sauf-conduit du monastère d'Apa Jeremias à Saqqara?“, Bulletin of the American Society of Papyrologists 53 (2016): 233-238. - Edition of a new Arabic safe-conduct, most probably from the monastery of Apa Jeremias at Saqqāra. The document in question (P. Pierpont Morgan inv. Ms M. 662 B.35e) was issued by a certain 'Īsā b. fulān, fiscal agent ('âmil), for an anonymous person traveling from Memphis in Dhū al-qa'da 110/February-March 729. The document gives 
the pass holder the permission to travel to Fusțāt to work for a period of one to two months. - The editors read bi-fusțatt at the beginning of line 5, whereas the upper traces of the lām are still visible. In my eyes, the correct reading would be [bi-](5)l-fusțāt; the word was split across lines 4 and 5, [bi-] would have been written at the end of line 4. (Younes)

76. Rāğib, Yūsuf, „Au sujet d'un mot introuvable dans les dictionnaires“, Arabica 63 (2016): 681-687. - Im amtlichen Brief P. Ryl.inv.F IV 1r.4 (141/759; al-Ušmūnayn) hatte RĀĠIB („Lettres de service ...“, Archéologie Islamique 3 (1992): 16 bzw. 6, Anm. 5) einen unpunktierten Graph kommentarlos einmal ğaytar „petit“, einmal ğasim gelesen; DiEm („Three Remarkable Documents ....", in: Kaplony, Andreas et al. (Hrsg.), From Bāwìt to Marw ..., Leiden 2015, 14) hatte ğaytar in den Wörterbüchern nicht gefunden und daher ğasīm „corpulent“ vorgezogen. RĀǴIB liefert nun die Belege aus den Wörterbüchern für ğaytar und die Homographen ğaydar, habtar, hintar und hanbar nach. Von Bild her scheint mir die Lesung ğasìm nahezuliegen. (Kaplony)

77. Rāğib, Yūsuf, „Lettre relative à la location d'une chambre au début du IIIe/ IXe siècle“, Annales Islamologiques 49 (2015 [lies: 2016]): 145-159. - Edition, Übersetzung und Kommentar zu einem arabischen Brief (P. Beatty 18; 9. Jh.), in dem es um eine frühere gezahlte Miete für ein Zimmer, um die Neuvermietung für 6-8 dīnār (pro Jahr?), und um den Verkauf einer Perle geht. (Kaplony)

78. Reinfandt, Lucian, „Versuchte Einflussnahme auf einen behördlichen Entscheidungsträger: P. Vind.inv. A.P. 15228 aus der Österreichischen Nationalbibliothek“, in: Gažáková, Zuzana / Drobný, Jaroslav (Hrsg.), Arabic and Islamic Studies in Honour of Ján Pauliny, Bratislava 2016, 367-384. - Edition, Übersetzung, Kommentar und wichtige Analyse von P. Vind.inv. A.P. 15228 (8.-9. Jh., Ägypten), der auf recto (sic) die Kopie einer Steuerliste, auf verso einen informellen Brief zwischen Kollegen trägt. Beide stammen von derselben Hand, verwenden aber, entsprechend den Dokumenttypen, verschiedene Schriften. Der Brief ist in der äußeren Form nachlässig, im Stil präzise. (Kaplony)

79. Reinfandt, Lucian, „Zum Schulunterricht im frühislamischen Ägypten“, in: Palme, Bernhard (Hrsg.), Hieroglyphen und Alphabete ..., Wien 2016, 47-58. Ein Überblick. (Kaplony)

80. Reinfandt, Lucian / Vanthieghem, Naïm, „Les archives fiscales de Mīnā, fils de Damarqūra, un contribuable copte du IXe siècle“, in: Fournet, JeanLuc / Papaconstantinou, Arietta (Hrsg.), Mélanges Jean Gascou ..., Paris 2016, 351-370. - R. und V. stellen sieben Steuerquittungen vor, die alle aus dem Umkreis eines Mīnā, Sohn des Damarqūra, stammen. Wie aus den guten Abbildungen aller Papyri ersichtlich, befinden sich noch Siegel auf den Quit- 
tungen. Die Papyri gehören zu einer Art Archiv, das von den beiden Autoren aus verschiedenen Papyrussammlungen zusammengetragen worden ist und das einen guten Einblick in die Abwicklung administrativer Abläufe rund um Steuerzahlungen im 3./9. Jahrhundert und in den historischen Hintergrund erlaubt. (Bsees)

81. Richter, Tonio Sebastian, „Neue koptische medizinische Rezepte“, Zeitschrift für Ägyptische Sprache und Altertumskunde 141 (2014): 154-194. - In seinem Beitrag, der recht bescheiden mit „Ergänzungen“ umschrieben wird, stellt R. vier Editionen koptischer medizinischer Rezepte vor. Sein Hauptfokus liegt klar auf der Arzneimittelkunde, und hierbei wiederum auf sprachlichen Aspekten. Die Behandlung geht deutlich über das Spektrum koptologischen Interesses hinaus, widerlegt R. doch die Annahme, dass koptische Rezepte eine ungebrochene Weiterführung altägyptischen medizinischen Wissens enthalten. Durch seine schlüssige Argumentation auf der Basis einer Analyse medizinischer Termini wird vielmehr klar, dass zuerst die griechische, dann die arabische Tradition die koptische Arzneimittelkunde und Medizin maßgeblich beeinflusst haben. (Bsees)

82. Richter, Tonio Sebastian, „Ein fatimidenzeitliches koptisches Rechnungsheft aus den Papieren Noël Girons“, in: Fournet, Jean-Luc / Papaconstantinou, Arietta (Hrsg.), Mélanges Jean Gascou ..., Paris 2016, 381-402.

83. Sartori, Paolo, „On Khvārazmian Connecticity: Two or Three Things That I Know about It“, Journal of Persianate Studies 9 (2016): 133-157. -Auch zur Geschichte der zentralasiatischen Archive und zur Regionalisierung Zentralasiens. (Kaplony)

84. Sartori, Paolo, „Seeing Like a Khanate: On Archives, Cultures of Documentation, and Nineteenth-Century Khvārazm“, Journal of Persianate Studies 9 (2016): 228-257. - S. greift u.a. die Unterscheidung der arabischen Papyrologie zwischen Dokumenten und narrativen/literarischen Quellen an: ein Dokument ist für ihn ,,any text which may serve as a resource for the substantiation - or the anticipated future substantiation - of some kind of claim or a belief“. - Entscheidend scheint mir der Unterschied zwischen Sachrest und Text: ein Geleitschein und eine literarische Handschrift sind als Sachreste beide Unikate und damit direkt vergleichbar, aber ein in einem Dokument nur einmal erhaltener Text und die untereinander verwandten Versionen eines in mehreren Handschriften erhaltenen Textes haben einen unterschiedlichen Quellenwert. (Kaplony)

85. Schenke, Gesa, „Two Papyri from Jeme“, in: Fournet, Jean-Luc / Papaconstantinou, Arietta (Hrsg.), Mélanges Jean Gascou ..., Paris 2016, 403-412.

86. Simonsohn, Uriel, „Communal Membership Despite Religious Exogamy: A Critical Examination of East and West Syrian Legal Sources of the Late Sasa- 
nian and Early Islamic Periods“, Journal of Near Eastern Studies 75 (2016): 249-266. - The 8th and 9th centuries signal the height of the codification of ecclesiastical law in the Middle East. S. focuses on the development of ecclesiastical matrimonial principles under Islamic domination and the crucial role of family law, with a focus on religious exogamy. (Kleiner)

87. Sohoni, Pushkar, „Paper Documents and Copper-Plates: Localization of Hegemonic Practices“, Bulletin of the School of Oriental and African Studies 79 (2016): 87-101. - Studie über persisch geschriebene Landschenkungsurkunden auf Kupferplatten aus dem indischen Dekkan. Für diese von Seiten des Sultans ausgestellten Urkunden auf ungewöhnlichem Schreibmaterial sind bislang keine vergleichbaren Beispiele bekannt. Sie stammen aus dem 16. Jahrhundert und aus jüngerer Zeit, gehen aber vermutlich auf ältere Originale auf vergänglicherem Trägermaterial zurück. Ausgehend von dieser besonderen Urkundenart behandelt S. die Materialität von Dokumenten im Bezug zu ihrem textlichen Gehalt sowie die Bedeutung des Trägermaterials von Urkunden für ihre Funktionalität in der Gesellschaft, am Beispiel des vormodernen und frühneuzeitlichen Indiens. (Reinfandt)

88. Stein, Peter / Jocham, Tobias J. / Marx, Michael, „Ancient South Arabian Correspondence on Wooden Sticks: New Radiocarbon Data“, Proceedings of the Seminar for Arabian Studies 46 (2016), 263-276. - Presentation of the $14 \mathrm{C}$ analysis of 29 South Arabian wooden sticks housed at the Bavarian State Library and considered representative of Ryckman's main palaeographical phases of South Arabian writing. Except for those falling within the so-called "Hallstatt plateau" (700-400 BCE), the results of the 14C dating essentially correlate with the palaeographical sequence. (Garosi)

89. Stern, Matthias, „Welche Gefängnisse kontrolliert der Pagarch?“, in: Derda, Tomasz et al. (Hrsg.), Proceedings of the 27th International Congress of Papyrology ..., Warschau 2016, 1843-1870.

90. Stokoe, Christopher / Ferrario, Gabriele / Outhwaite, Ben, „In the Shadow of Goitein: Text Mining the Cairo Genizah“, Manuscript Cultures 7 (2014): 29-34. - Wer sich heute die für ein Thema relevanten jüdisch-arabischen Dokumente zusammensucht, leidet unter ihrer großen Zahl und unter dem Fehlen von Katalogen (was der Aufwendigkeit der Katalogisierung geschuldet ist). Die Autoren schlagen nun vor, in publizierten Dokumenten vorkommende wichtige Begriffe automatisch mit den Metadaten derselben Dokumente $\mathrm{zu}$ verbinden, diese Begriffe in unpublizierten Dokumenten automatisch $\mathrm{zu}$ erkennen und so auch den unpublizierten Dokumenten Metadaten zuzuweisen. - Ein zukunftsweisender Ansatz, um die gründliche Katalogisierung von jüdisch-arabischen und arabisch-arabischen Dokumente mit einer oberflächlichen Schnellsuche zu ergänzen. (Kaplony) 
91. Thomann, Johannes, „An Arabic Horoscope on Parchment with a Square Diagram for AD 1002 (P. Vind.inv. A.Perg. 236)”, in: Derda, Tomasz et al. (Hrsg.), Proceedings of the 27th International Congress of Papyrology ..., Warschau 2016, 1085-1094. - The edited fragment is the oldest preserved square diagram in a non-Chinese document, and, as the older Chinese diagrams are not used for astrology, the oldest horoscope with a square diagram. The diagram form is well known in medieval Arabic, Greek, and Latin astrology. The use of parchment suggests that the horoscope was not kept by the astrologer, but handed over to the client. The planetary week is also mentioned. (Sonego)

92. Tillier, Mathieu / Vanthieghem, Naïm, „La rançon du serment: un accord à l'amiable au tribunal fatimide de Talīt“, Revue des mondes musulmans et méditerranéens 140 (2016): 53-72. - Edition, Übersetzung und Analyse des Protokolls (P. Lond.inv. Or.Ms. 4927 (3); 404/1013; Talìt im Fayyūm) einer Vergleichsverhandlung im Verwaltungszentrum Ṭalịt. Ein Christ aus dem benachbarten, mehrheitlich christlichen Ṭuṭūn zahlt einen halben Dīnār an den ġulām so-und-so al-muslimānī, also Neu-Muslim, der die Erben seines Herrn vertritt, und vermeidet damit den Schwur, dass er dem Verstorbenen einen Geldbetrag zurückgezahlt hat. (Kaplony)

93. Vanthieghem, Naïm, „La correspondance de Qurra b. Šarīk et de Basileios revisitée. I. À propos d'une lettre récemment publiée“, Chronique d'Égypte 91 (2016): 204-210 - Befasst sich mit dem von Donner („Fragments of Three Umayyad Official Documents“, in: Pomerantz, Maurice A. / Shahin, Aram (Hrsg.), The Heritage of Arabo-Islamic Learning ..., Leiden 2015, 30-47) publizierten arabischen Papyrus P. Vind.inv. A.P. 6672. V. erkennt das Fragment als mit P. Heid.Arab. I 14+16 zusammengehörig, sieht darüber hinaus aber auch eine Zusammengehörigkeit mit P. Cair.Arab. 146. Das Ergebnis wäre die Vervollständigung des in Kairo befindlichen langen Briefs des arabischen Statthalters von Ägypten, Qurra b. Sharīk aus dem Jahr 91/710 um den bislang fehlenden Briefanfang und, darüber hinaus, eine spektakuläre Zusammenfügung von mehreren Fragmenten aus unterschiedlichen Sammlungen in drei Ländern und auf zwei Kontinenten. - V. ist für seine Initiative und sein bewundernswert gutes Auge zu danken, denn die Fragmente aus Wien und Heidelberg dürften, wie ein Blick auf die beiliegenden Fototafeln zeigt, tatsächlich zusammengehören. Nicht überzeugt hingegen die behauptete Zusammengehörigkeit mit dem wesentlich größeren Kairoer Fragment, denn hier sind Schriftbild, Layout und Trägermaterial doch von ganz anderer Beschaffenheit. (Reinfandt)

94. Vanthieghem, Naïm, „Le dossier fiscal de Sa'dūn b. Abū Hamza. Réédition de P. Ryl. Arab. I, III 6“, Chronique d'Egypte 91 (2016): 427-432. - Neuedition 
der Steuerquittungen P. Ryl.Arab. I III 6 (279/892; Edfu); 1 (= P. Ryl.Arab. II 2); 4; 9; 10; 11; 12; CPR XXI 49. (Kaplony)

95. Vanthieghem, Naïm, „Une contribution pour la table d'un prince ikhchidide: édition de P. Utah Inv. 1383“, Chronique d'Egypte 91 (2016): 433-436. Ein Zahlungsbefehl, die Kosten der Tafel des amīr Abū l-Ḥasa[n] (li-țaman mā'idat al-amīr abī l-hasa[n]) für die Periode Shawwāl 342 bis Ǧumādā II 343/8. Februar - 30. Oktober 954 zu übernehmen. (Kaplony).

96. Vanthieghem, Naïm, „Violences et extorsions contres des moines dans la région d’Assiout. Rééedition de P. Ryl.Arab. II 11“, Journal of Coptic Studies 18 (2016): 185-196. - Neuedition, Übersetzung und philologischer Kommentar zur Petition P. Ryl.inv. Arab. Add. 354 (9.-10. Jh.; wohl Asyūṭ oder al-Ušmūnayn). Die Erstedition von Smith/al-Moraekhi (P. Ryl.Arab. II 11; 1996) war schon von DiEm (Journal of Semitic Studies 43 (1998): 104-110) ausführlich besprochen worden. (Kaplony)

97. Verreth, Herbert, „Topography of Egypt Online“, in: Derda, Tomasz et al. (Hrsg.), Proceedings of the 27th International Congress of Papyrology ..., Warschau 2016, 1379-1385. - The Trismegistos database (www.trismegistos.org) provides information on ancient and modern places names, further references, provenances, and collections for all documents „from Egypt and abroad" from the eighth century BC till the eighth century AD. Arabic documents and terms are fully integrated. (Kaplony)

98. von Falkenhausen, Vera / Jamil, Nadia / Johns, Jeremy, „The Twelfth-Century Documents of St. George's of Tròccoli Sicily“, Journal of Arabic and Islamic Studies 16 (2016): 1-84. - Edition and study of six 12th-century documents preserved in Toledo at the Casa de Medinaceli. Written in GreekArabic and Arabic and issued by King Roger, they are of some paleographical, topographical, and social interest: famine in Ifriqiyya brought Muslim peasants to work for the monastery. (Daga Portillo)

99. Wasserstein, David J., „Straddling the Bounds: Jews in the Legal World of Islam“, in: Echevarria, Ana et al. (Hrsg.), Law and Religious Minorities in Medieval Societies ..., Turnhout 2016, 73-82. - Analysis of the role of Hebrew documents in Islamic courts. Three cases show how documents were ignored or remitted to the Jewish court. The Jewish community used language as boundary, yet boundaries were straddled when needed. Oral legal language predominated till the 12th century. (Daga Portillo)

100. Wissa, Miriam, „,Twenty-five Hundred knidia of Wine... and Two Boats to Transport the Wine to Fustāt': An Insight into Wine Consumption and Use amongst the Dhimmīs and Wider Communities in Umayyad Egypt“, in: Echevarria, Ana et al. (Hrsg.), Law and Religious Minorities in Medieval Societies ..., Turnhout 2016, 101-110. - Wine consumption in Umayyad Egypt is 
documented in papyri, ostraca, pieces of Islamic art, and narrative sources. Taxes revenue encouraged a trade where Muslim and non-Muslim were involved. Edfu and the Monastery of Apa Tomas, Wadi Sarga, were big production centers. (Daga Portillo)

101. Younes, Khaled M., „An Arabic Acknowledgment of a Debt on Papyrus“, Archiv für Papyrusforschung 62 (2016): 195-202. - Edition des Verpflichtungsscheins P. Vind.inv. A.P. 980 (244/858; Ägypten), dessen Formular Y. als dem Formular von dikr haqq-Urkunden folgend rekonstruiert. Unterhalb des eigentlichen Urkundentextes auf recto sowie weiterführend auf verso finden sich fünf Zeugenunterschriften, die die Richtigkeit des Rechtsgeschäfts, eines Terminkaufs, bestätigen. Damit legt Y. ein weiteres Zeugnis dieser vor allem in Thung, CPR XXVI (2006) und DIEM, Arabischer Terminkauf (2006) behandelten Urkundengattung vor. (Reinfandt)

102. Younes, Khaled, „Two Arabic Papyrus Documents Relating to Payments in Kind“, Bulletin of the American Society of Papyrologists 53 (2016): 239-251. Edition zweier Urkunden zu Termingeschäften arabischer Papyri, P. Cam. Michaelides B 718 und B 118 (9. Jh. bzw. 262/875; Ägypten). In der ersten verpflichtet sich Aussteller zur Lieferung von 4 Artaben Weizen. Die zweite verpflichtet zur Lieferung von Viehfutter im Umfang von 1300 Körben Klee oder Luzerne (qurț). Beide Urkunden folgen demselben Formular, sind vollständig erhalten und sind eine wichtige Erweiterung der bislang bekannten Texte dieser Art von Rechtsgeschäft. (Reinfandt)

103. Zinger, Oded, „From an Arab Queen to a Yiddische Mama: The Travels of Marital Advice around the Medieval Mediterranean“, Medieval Encounters 22 (2016): 471-516. - Z. explores the travels of a literary anecdote about a young married woman in the medieval Mediterranean. Tracing its various incarnations allows us to understand translation and adaptation processes influenced by cultural transmission, as well as the commonalities and differences in normative gender roles in different societies. (Kleiner)

\section{E Besprechungen}

104. Altıntaş, Abdulmennan M., Review of: Aslanian, Sebouh David, From the Indian Ocean to the Mediterranean: The Global Trade Networks of Armenian Merchants from New Julfa, Berkeley 2011, Archiv Orientálni 83 (2015): 203-204.

105. Bauden, Frédéric, Review of: Bausi, Alessandro (Hrsg.), Comparative Oriental Manuscript Studies ..., Hamburg 2015, Bulletin of the School of Oriental and African Studies 79 (2016): 171-173. 
106. Bauden, Frédéric, Review of: Mouton, Jean-Michel / Sourdel, Dominique / Sourdel-Thomine, Janine, Mariage et séparation à Damas au moyen âge: un corpus de 62 documents juridiques inédits entre 337/948 et 698/1299, Paris 2013 (Documents relatifs à l'histoire des croisades 21), Bulletin of the School of Oriental and African Studies 78 (2015): 182-184.

107. Biesterfeldt, Hinrich, Besprechung von: Lewicka, Paulnia B., Food and Foodways of Medieval Cairenes: Aspects of Life in an Islamic Metropolis of the Eastern Mediterranean, Leiden 2011 (Islamic History and Civilization. Studies and Texts 88), Der Islam 92 (2015): 530-533.

108. Diem, Werner, Besprechung von: Kaplony, Andreas, Fünfundzwanzig arabische Dokumente aus dem Rotmeer-Hafen al-Qușayr al-Qadìm (7./13. Jahrhundert) [P. QuseirArab. II]: Edition, Übersetzung und Kommentar, Leiden 2014 (Islamic History and Civilization: Studies and Texts 109), Der Islam 93 (2016): 268-285.

109. Elger, Ralf, Besprechung von: Lehmann, Anne-Geelke, Die Ernennungsurkunde eines Sufis aus dem Syrien des 18. Jahrhunderts, Würzburg 2011 (Arbeitsmaterialien zum Orient 25), Zeitschrift der Deutschen Morgenländischen Gesellschaft 164 (2014): 556-558.

110. Frenkel, Mirjam, Review of: Ackerman-Lieberman, Phillip I., The Business of Identity ..., Stanford 2014, Journal of the American Oriental Society 136 (2016): 640-643.

111. Ghosh, Shami, Review of: Goldberg, Jessica L., Trade and Institutions in the Medieval Mediterranean: The Geniza Merchants and Their Business World, Cambridge / New York 2012 (Cambridge Studies in Economic History. Second Series), Medieval Review 14.2.8 (2014).

112. Gordon, Matthew S., Review of: Sijpesteijn, Petra M., Shaping a Muslim State: The World of a Mid-Eighth-Century Egyptian Official, Oxford 2013 (Oxford Studies in Byzantium), Bulletin of the School of Oriental and African Studies 77 (2014): 576-577.

113. Guo, Li, Review of: Lewicka, Paulnia B., Food and Foodways ..., Leiden 2011, International Journal of Middle East Studies 45 (2013): 833-835.

114. Hirschler, Konrad, Review of: Mouton, Jean-Michel / Sourdel, Dominique / Sourdel-Thomine, Janine, Gouvernance et libéralités de Saladin d'après les données inédites de six documents arabes, Paris 2015 (Documents relatifs à l'histoire des croisades publiés par l'Académie des inscriptions et belleslettres 22), Der Islam 93 (2016): 286-290.

115. Hundhammer, Marianus, Besprechung von: Schönig, Hanne / Rodinov, Mikhail, The Hadramawt Documents, 1904-1951: Family Life and Social Customs under the Last Sultans, Würzburg 2011 (Beiruter Texte und Studien 130), Wiener Zeitschrift für die Kunde des Morgenlandes 103 (2013): 491-494. 
116. Lahcen, Daaïf, Compte-rendu de: Müller, Christian, Der Kadi und seine Zeugen: Studie der mamlukischen Haram-Dokumente aus Jerusalem, Wiesbaden 2013 (Abhandlungen für die Kunde des Morgenlandes 85), Bulletin Critique des Annales islamologiques 28 (2013): 44-46.

117. Leder,Stefan, Besprechung von:Aigle, Denise/Péquignot, Stéphane(Hrsg.), La correspondance entre souverains, princes et cités-états: approches croisées entre l'Orient musulman, l'Occident latin et Byzance (XIII-début XVIe siècle), Turnhout 2013 (Miroir de l'Orient musulman 2), Orientalistische Literaturzeitung 110 (2015): 477-479.

118. Liebrenz, Boris, Besprechung von: Mouton, Jean-Michel et al., Mariage et séparation à Damas ..., Paris 2013, Archiv für Papyrusforschung 60 (2014): 258-263.

119. Liebrenz, Boris, Besprechung von: Diem, Werner, Arabische Briefe auf Papier aus der Heidelberger Papyrus-Sammlung, Heidelberg 2013 (Veröffentlichungen aus der Heidelberger Papyrus-Sammlung. N.F. 13), Orientalistische Literaturzeitung 110 (2015): 233-236.

120. Liebrenz, Boris, Besprechung von: Müller, Christian / Roiland-Rouabah, Muriel (Hrsg.), Les non-dits du nom: Onomastique et documents en terres d'Islam. Mélanges offerts à Jacqueline Sublet, Beirut 2013, Der Islam 92 (2015) 533-541. - Eine sehr positive Bewertung. (Kaplony)

121. Liebrenz, Boris, Review of: Mouton, Jean-Michel et al., Gouvernance et libéralités de Saladin ..., Paris 2015, Bulletin of the School of Oriental and African Studies 79 (2016): 406-407.

122. Liebrenz, Boris, Review of: Sijpesteijn, Petra M., Shaping a Muslim State ..., Oxford 2013, Der Islam 93 (2016): 320-326.

123. Milwright, Marcus, Review of: Talmon-Heller, Daniella / Cytryn-Silverman, Katia (Hrsg.), Material Evidence and Narrative Sources: Interdisciplinary Studies of the History of the Muslim Middle East, Leiden 2015 (Islamic History and Civilization. Studies and Texts 108), Bulletin of the School of Oriental and African Studies 78 (2015): 610-612.

124. Papaconstantinou, Arietta, Review of: Kaplony, Andreas / Potthast, Daniel / Römer, Cornelia (Hrsg.), From Bāwīt to Marw: Documents from the Medieval Muslim World, Leiden 2015 (Islamic History and Civilization: Studies and Texts 112), Journal of Religion in Europe 9 (2016): 294296.

125. Péquignot, Stéphane, Compte-rendu de: Beihammer, Alexander / Parani, Maria / Schabel, Christoph (Hrsg.), Diplomatics in the Eastern Mediterranean 1000-1500: Aspects of Cross-Cultural Communication, Leiden 2008 (The Medieval Mediterranean 74), Bulletin d' Etudes Orientales 62 (2013). Nur online erschienen (Kaplony) 
126. Peskes, Esther, Besprechung von: Rodinov, Mikhail / Schönig, Hanne, The Haḍramawt Documents ..., Würzburg 2011, Welt des Islams 55 (2015): 122-127.

127. Reinfandt, Lucian, Besprechung von: Lepper, Verena M. (Hrsg.), Forschung der Papyrussammlung: eine Festgabe für das Neue Museum, Berlin 2012 (Ägyptische und Orientalische Papyri und Handschriften des Ägyptischen Museums und Papyrussammlung Berlin 1), Wiener Zeitschrift für die Kunde des Morgenlandes 104 (2014): 433.

128. Shatzmiller, Maya, Review of: Frenkel, Miriam / Lev, Yaacob (Hrsg.), Charity and Giving in Monotheistic Religions, Berlin / New York 2009 (Studien zu Geschichte und Kultur des islamischen Orients. Beihefte zur Zeitschrift „Der Islam“. N.F. 22), Der Islam 92 (2015): 249-253. - Sh. betont, dass Almosen auch eine starke wirtschaftliche Bedeutung haben und gesellschaftliche Ungleichheit nicht etwa schwächen, sondern aufrecht erhalten. (Kaplony)

129. Tuchscherer, Michel, Compte-rendu de: Hanna, Nelly, Ottoman Egypt and the Emergence of the Modern World 1500-1800, Kairo / New York 2014, Bulletin of the School of Oriental and African Studies 79 (2016): 188-190.

130. van Bekkum, Wout, Review of: Wagner, Esther-Miriam, Linguistic Variety of Judaeo-Arabic in Letters from the Cairo Genizah, Leiden 2010 (Etudes sur le judaïsme médiévale 41), Bibliotheca Orientalis 70 (2013): 478-481.

131. Vanthieghem, Naïm, „Opérations comptables dans un ordre de paiement arabe: à propos de P. Vindob. inv. A.P. 3172“, Bulletin of the American Society of Papyrologists 53 (2016): 372-373. - Zu Sijpesteijn, „Making the Private Public ...“, Studia Orientalia Electronica 2 (2014): 74-91.

132. Vanthieghem, Naïm, Compte-rendu de: Kaplony, Andreas, Fünfundzwanzig arabische Dokumente ..., Leiden 2014, Le Muséon 129 (2016): 236-238.

133. Vanthieghem, Naïm, Compte-rendu de: Sijpesteijn, Petra M., Shaping a Muslim State ..., Oxford 2013, Le Muséon 129 (2016): 238-241.

134. Vanthieghem, Naïm, „Papyrologica III. 23: Les textes arabes de la Geniza du Caire; 24: CPR III, Nachträge und Berichtigungen'; 25: P. Berl.Arab. I 4; 26: P. Frantz-MurphyTransformation. 27: P. HanafiTwoArabicDocuments 1. 28: P. HanafiTwoArabicDocuments 2. 29: P. HanafiWill. 30: P. SijpesteijnTroubles“, Chronique d'Egypte 91 (2016): 220-224.

135. Vanthieghem, Naïm, „Papyrologica IV. 34: CPR III 145; 35: P. David-Weill Louvre II; 36: P. DonnerFragments 2“, Chronique d'Egypte 91 (2016): 443-445.

136. Walker, Iain, Review of: Schönig, Hanne / Rodinov, Mikhail, The Haḍramawt Documents ..., Würzburg 2011, Zeitschrift der Deutschen Morgenländischen Gesellschaft 165 (2015): 225-228.

137. Wolper, Ethel Sarah, Review of: Trépanier, Nicolas, Foodways and Daily Life in Medieval Anatolia ..., Austin 2014, Bulletin of the School of Oriental and African Studies 79 (2016): 408-409. 


\section{F Bibliographie}

138. Berkes, Lajos / Bsees, Ursula / Daga Portillo, Rocio / Garosi, Eugenio / Kaplony, Andreas / Lindstedt, Ilkka / Metz, Sebastian / Potthast, Daniel / Reinfandt, Lucian / Sonego, Leonora / Younes, Khaled / Zinger, Oded, zusammengestellt von Kaplony, Andreas, „Bibliographie raisonnée zur arabischen Papyrologie: Neuerscheinungen 2015 und Nachträge 2013-2014“, Der Islam 93 (2016): 532-580.

Pascal Buresi, Hicham El Aallaoui, Gouverning the Empire: Provincial Administration in the Almohad Caliphate (1224-1269), Critical Edition, Translation, and Study of Manuscript 4752 of the Hasaniyya Library in Rabat (Studies in the History and Society of the Maghrib 3), Leiden: Brill, 2013, ISBN 978-90-04-23333-1.

Besprochen von Daniel Potthast, Ludwig-Maximilians-Universität München, München, Deutschland, daniel.potthast@lmu.de

https://doi.org/10.1515/islam-2017-0031

Pascal BuRESI und Hicham El AALlAOUi studieren und edieren in dieser Monographie ein Handschriftenunikum, das eine Sammlung von Dokumenten der almohadischen Kanzlei enthält. Der Verfasser der Sammlung wird im Manuskript nur Yahyā genannt. Die Editoren identifizieren ihn rein spekulativ mit Yahyyā al-Ḩadūğğ (1196-1268), dem eine solche Sammlung zugeschrieben wird. Im Manuskript, das selbst wohl ins 16. oder 17. Jahrhundert zu datieren ist, ergänzt Yahyyā eine kürzere Sammlung eines anonymen šayhs um weitere almohadische Dokumente. Der Handschrift ist unvollständig; sie enthält 77 Ernennungsschreiben (taqdīm: Nr. 1-48 für militärische und administrative Ämter, Nr. 49-77 für Richter). Laut den wenigen kommentierenden Passagen sind Abschnitte mit weiteren Dokumenttypen (șakk, z̧āhir, 'ahd, mukātaba) verloren. Fast alle Dokumente sind anonymisiert worden, sprich es fehlen Daten, Orts- und Personenamen. Auch das Protokoll und Eschatokoll der Dokumente wurde meist weggelassen.

Nach den wenigen Dokumenten, die sich datieren lassen (zwischen 1224 und 1246), handelt es sich um Beispiele aus den letzten Jahren des Almohadenreichs. Die Dokumente 5, 30, 54 und 55 stammen dagegen aus der Kanzlei Ibn Hūd alMutawakkils, dem wichtigsten Gegner der Almohaden im Andalus jener Zeit. Die fehlende genaue historische Einordnung der almohadischen Dokumente verringert ihren Wert beträchtlich, da sie sich nur bedingt den verschiedenen Phasen vor und nach al-Ma'mūns Abkehr vom Almohadismus und nach ar-Rašīds Rückkehr zu ihm zuordnen lassen. 